\title{
Pengembangan Teknologi E-Marketplace Hasil Bumi di Desa Tumbang Manjul
}

\author{
Dendi Sugito, Lukman Bachtiar* \\ Fakultas Ilmu Komputer, Program Studi Sistem Informasi, Universitas Darwan Ali, Sampit, Indonesia \\ Email: 1dendisugito2708@gmail.com, 2,"lukman.bachtiar@gmail.com \\ Submitted: 22/08/2021; Accepted: 30/08/2021; Published: 31/08/2021
}

\begin{abstract}
Abstrak-Masyarakat tumbang manjul merupakan Penduduk yang berada di daerah pelosok, terletak di wilayah Kabupaten Seruyan Kecamatan Seruyan Hulu dengan kondisi Sumber Daya Alam yang begitu melimpah. Dengan adanya usaha yang di lakukan masyarakat, maka usaha tersebut memiliki masalah yang cukup serius untuk di perhatikan, melihat hal tersebut kurang optimal, maka perlu adanya solusi, sehingga konsumen dari luar daerah juga bisa meninjau hasil bumi dari usaha yang di tekuni Masyarakat Tumbang Manjul tersebut dengan adanya sistem informasi E-marketplace, pemasaran yang dilakukan para penjual bisa menjangkau seluruh area yang lebih luas khususnya Kalimantan Tengah dikarena pembeli yang datang bisa dari berbagai daerah yang lebih jauh.
\end{abstract}

Kata Kunci: Pengembangan; Teknologi; E-Marketplace; Hasil Bumi; Desa Tumbang Manjul5

Abstract-The Tumbang Manjul community is a resident in remote areas, located in the Seruyan Regency, Seruyan Hulu District with abundant natural resources. With the efforts carried out by the community, the business has a serious enough problem to pay attention to, seeing it is less than optimal, it is necessary to have a solution, so that consumers from outside the region can also review the produce from the business in the Tumbang Manjul Community. With the existence of an Emarketplace information system, marketing carried out by sellers can reach a wider area, especially Central Kalimantan, because buyers who come can come from various regions further afield.

Keywords: Development; Technology; E-Marketplace; Earth Products; Tumbang Manjul Village5

\section{PENDAHULUAN}

Saat ini kita telah berada dalam sebuah era yang sangat erat dengan teknologi komunikasi dan informasi, Kemajauan teknologi telah memberikan sumber (resources) informasi dan komunikasi yang amat luas dari apa yang telah dimiliki manusia. Teknologi dibidang pertanian telah banyak ditemukan sehingga menghasilkan produk pertanian yang berlimbah ruah. Namun, sistem manajemen penjualan tidak diperbaharui akan menjadi masalah sehingga perekonomian tidak meningkat.

Petani Indonesia harus tanggap terhadap laju perkembangan teknologi, Semua teknologi bisa dipelajari tak terkecuali dipelajari oleh kaum petani Indonesia, perkembangan teknologi tersebut dapat mendukung sistem usaha pertanian. Selain untuk mencari informasi tentang budidaya pertanian, juga bisa sebagai sarana komunikasi dengan petani lainnya dan juga untuk fungsi pemasaran produk pertanian[1].

Masyarakat tumbang manjul merupakan Penduduk yang berada di daerah pelosok, terletak di wilayah Kabupaten Seruyan Kecamatan Seruyan Hulu dengan kondisi Sumber Daya Alam yang begitu melimpah. Dengan adanya usaha yang di lakukan masyarakat, maka usaha tersebut memiliki masalah yang cukup serius untuk di perhatikan,melihat hal tersebut kurang optimal, Maka perlu adanya solusi, sehingga konsumen dari luar daerah juga bisa meninjau hasil bumi dari usaha yang di tekuni Masyarakat Tumbang Manjul tersebut[2].

Salah Satu komoditas Perkebunan yang masih tersisa dari kebakaran yang sering terjadi di Kalimantan ialah karet, bagi warga Kalimantan Tengah, karet adalah komoditas yang di budidayakan secara turun temurun. Tercatat luas kebun karet di Kalimantan Tengah pasca kebakaran sekitar 446.600 hektar. Selain ditanam sebagai komoditas utama, karet juga ditanam dengan tanaman lain secara tumpangsari untuk pola kebun campuran (agroforestry).

Ekspor sarang burung walet termasuk juga komoditas unggulan di Indonesia, terlihat di data tahun 2018 tercatat Mencapai Rp. 40 triliun hasil Ekspor. Ini merupakan potensi besar kita yang terbukti menghasilkan devisa, hanya memang tata niaga kita belum berjalan secara baik, pemerintah juga memberi perhatian khusus pada sarang burung walet kotor yang masih berusaha di Ekspor ke negara China[3].

Permasalahan yang sedang di hadapi, tidak stabilnya penjualan oleh pelaku permainan tengkulak, masyarakat tidak bisa melakukan promosi hasil bumi yang mereka hasilkan, dan tidak bisa mengetahui harga jual terupdate menjadikan pejualan hasil bumi menjadi terhambat. Dengan adanya permasalahan tersebut, maka solusi yang di tawarkan ialah membuat sistem informasi yang bisa menampung para penjualan dan pembelian dalam mepromosikan dan memasarkan hasil bumi yang dihasilkan[4].

Dengan adanya sistem informasi E-marketplace, pemasaran yang dilakukan para penjual bisa menjangkau seluruh area yang lebih luas khususnya Kalimantan Tengah dikarena pembeli yang datang bisa dari berbagai daerah yang lebih jauh, dan dengan adanya bantuan media teknologi berupa sistem informasi masyarakat dapat dengan mudah mempromosikan ke berbagai daerah dengan praktis dan mudah, dan juga dapat membantu masyarakat serta bisa melihat harga jual tebaru[5]. 


\section{METODOLOGI PENELITIAN}

\subsection{Metode Pengumpulan Data (Penggalian Informasi)}

Adapun Data yang dapat saya simpulkan mengenai di Toko Dalwa Zain Collection sebagai berikut :

a. Wawancara (interview)

Yaitu teknik pengumpulan data dengan cara tanya jawab langsung kepada kepala dinas, staff terkait dan para petani di desa Tumbang Manjul untuk mendapatkan informasi yang diperlukan. Dengan mencatat informasi hasil wawancara yang didapatkan kepada narasumber.

b. Observasi (Observation)

Yaitu teknik pengumpulan data dengan cara melihat data langsung pada proses pengolah data yang sudah ada maupun mencari data dengan mengolah data pada dinas ataupun petani dan masyarakat sekitar.

c. Studi perpustakaan (Library Research)

Studi pustaka merupakan metode pengumpulan data yang dilakukan dengan membaca buku-buku, literatur, jurnal-jurnal, referensi yang berkaitan dengan penelitian ini dan penelitian terdahulu yang berkaitan dengan penelitian yang sedang dilakukan.

\subsection{Pengembangan E-Market Place Pertanian Dengan Metode Prototype}

Aplikasi yang berhubungan dengan E-marketplace agribisnis dapat dikategorikan dari sudut pandang petani menurut faktor produksi, layanan, dan luaran. Untuk mengatasi permasalahan yang sudah diuraikan maka perlu dikembangkan sebuah sistem e-marketplace khusus pertanian untuk mengembangan. Dari Penelitian ini, mengembangkan E-Market Place Pertanian Dengan Metode Prototype untuk persaingan di era Digitalisasi ini[6].

\section{HASIL DAN PEMBAHASAN}

Analisis terhadap sistem yang sedang berjalan adalah suatu kegiatan untuk mempelajari interaksi sistem yang terdiri atas pelaku proses dalam sistem, prosedur, dan data serta informasi yang terkait. Kegiatan ini menggambarkan suatu sistem pada model yang dapat mengidentifikasi seluruh aspek yang terlibat dalam sistem tersebut[7]

\subsection{Rancangan Model Sistem}

Model dari sistem informasi dirancang dalam bentuk logika. Permodelan tersebut digambarkan dalam beberapa bagan, diantaranya Bagan Konteks (Context Diagram)

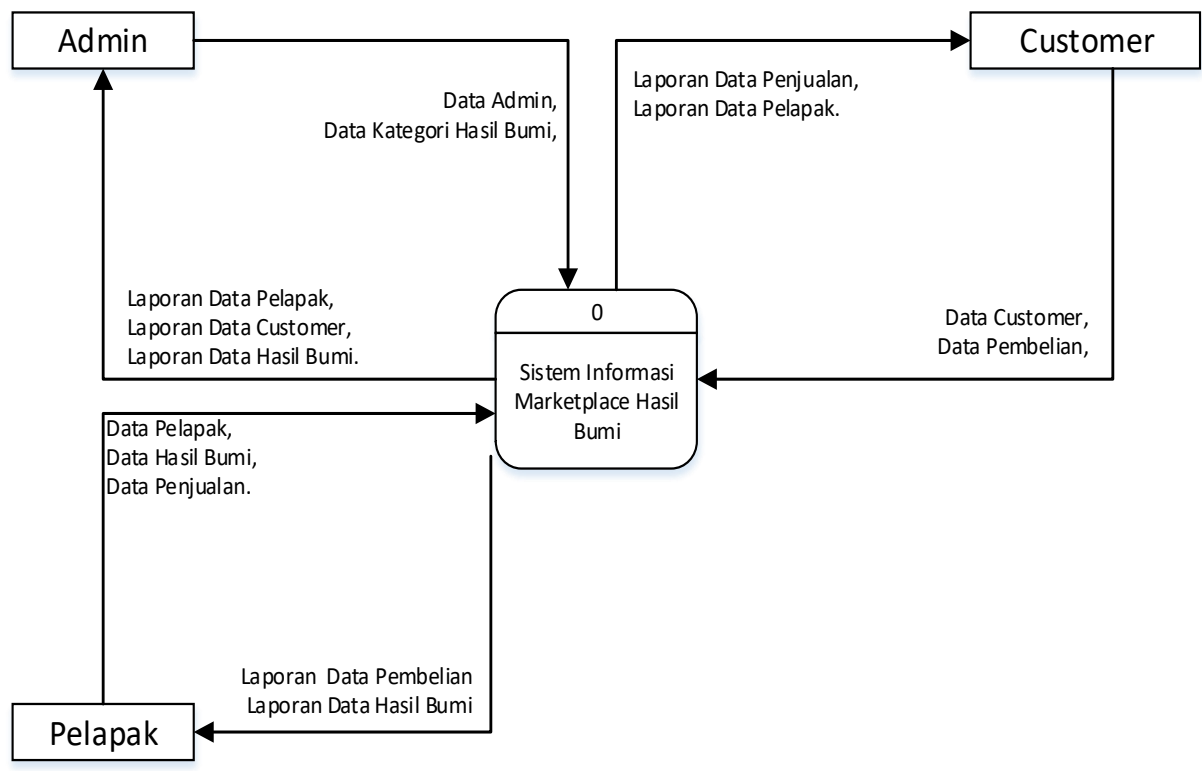

Gambar 1. Rancangan Data Flow Diagram

\subsection{Implementasi Program}

Tahap implementasi merupakan tahap akhir dari proses membangun sebuah sistem informasi. Pada tahap ini seluruh rancangan yang sudah dihasilkan, diterjamaahkan dengan mengunakan bahasa pemrograman sehingga menghasilkan sebuah sistem. Dalam impementasi sistem informasi pendaftaraan Pajak Bumi dan Bangunan pada dinas pendapatan daerah kabupaten Kotawaringin Timur berbasis web dilakukan dengan mengunakan alamat http://localhost. Pengujian yang dilkukan dengan mengunakan web browser Google Crome yang kemudian akan 
Journal of Computer System and Informatics (JoSYC)

Volume 2, No. 4, August 2021, Page 310-315

ISSN 2714-8912 (media online)

ISSN 2714-7150 (media cetak)

DOI 10.47065/josyc.v2i4.850

tampil interface halaman utama (Index). Pada Form utama terdapat beberapa menu dan fitur yang berfungsi untuk mengendalikan program aplikasi sesuai keinginan user.

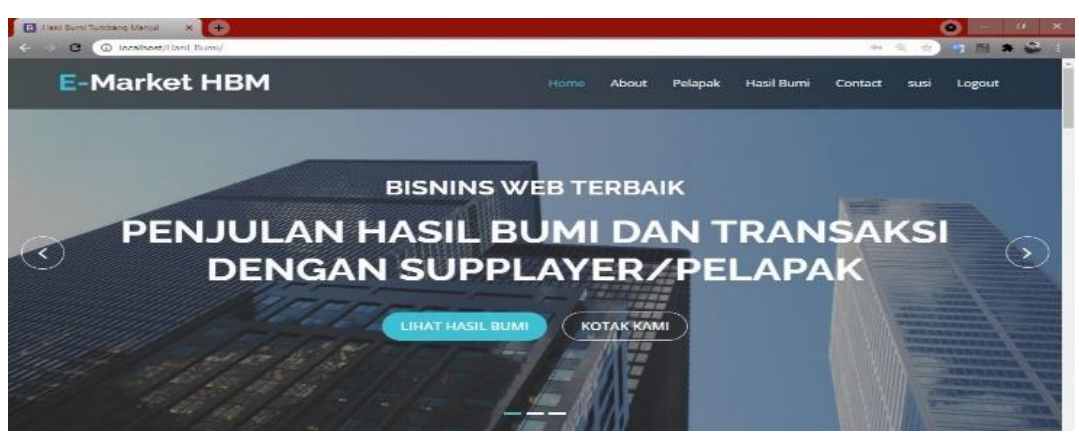

Gambar 2. Halaman Utama dan Form Login Pelapak dan Custumer

Interface halaman utama merupakan tampilan awal pada saat program pertama kali dijalankan, pada kesempatan ini mengunakan Google Crome dengan alamat http://localhost/Hasil_Bumi/index.php dengan nama file index.php. Berikut ini adalah tampilan halaman utama (Index).

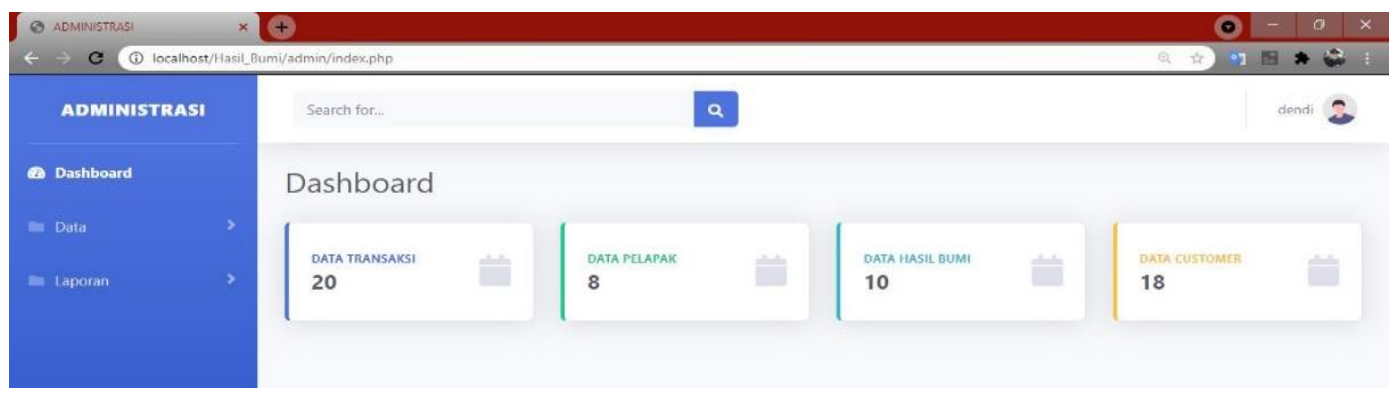

Gambar 3. Interface Daftar Submenu Data Master

Pada gambar di bawah ini merupakan data hasil bumi. Pada interface yang digunakan di lengkapi dengan fasilitas searching.

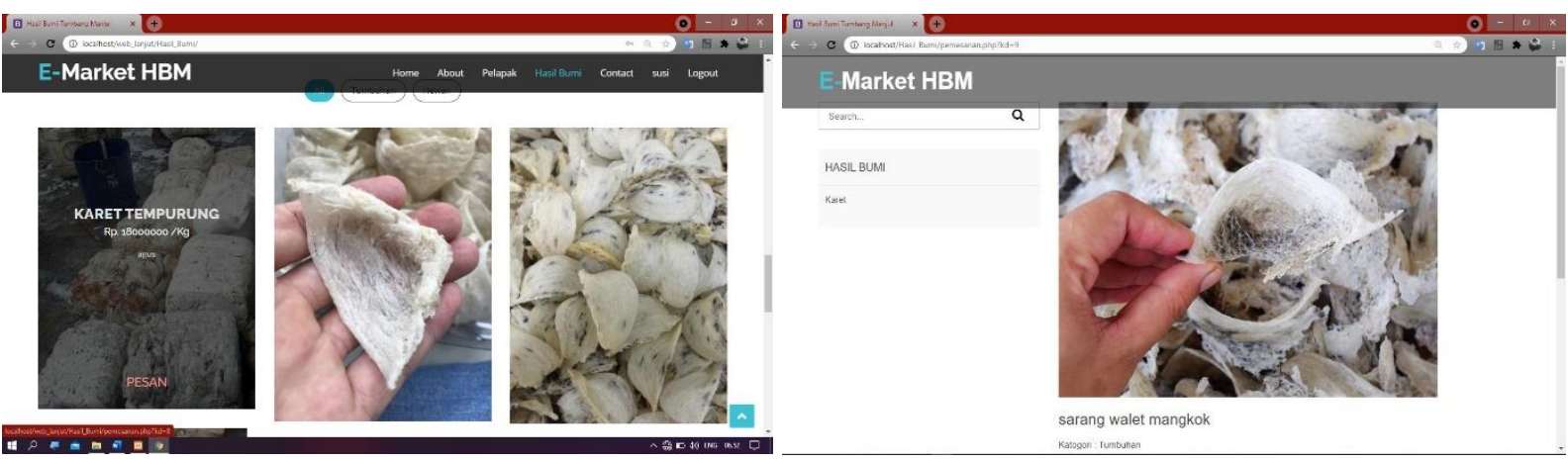

Gambar 4. Interface Daftar Submenu Data Transaksi

Interface di pada gambar 5 merupakan gambar sub menu laporan. Terdapat beberapa laporan yang di hasilkan dari website E-Marketplace Hasil Bumi.

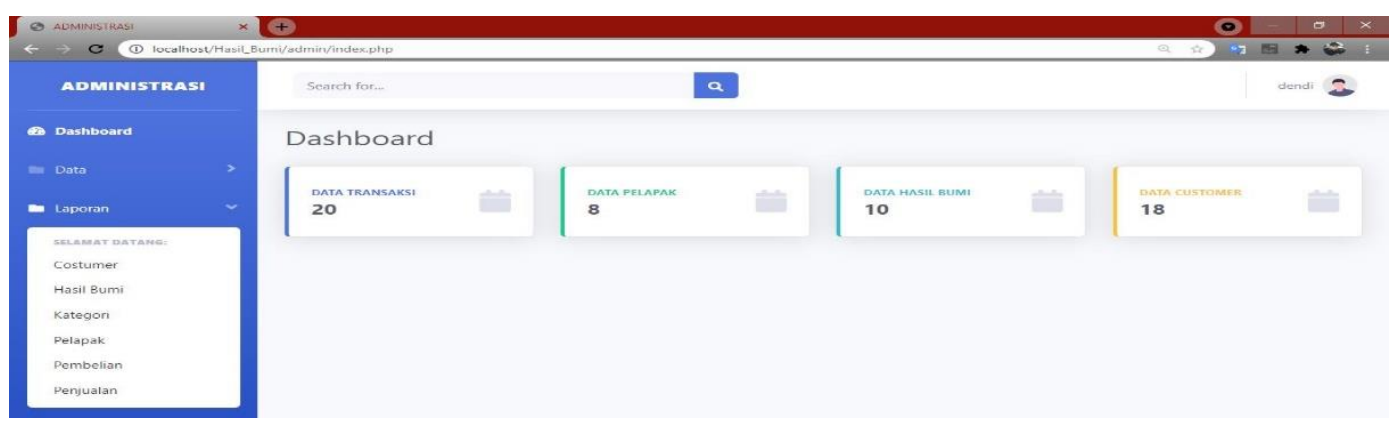

Gambar 5. Interface Daftar Submenu Laporan 
Journal of Computer System and Informatics (JoSYC)

Volume 2, No. 4, August 2021, Page 310-315

ISSN 2714-8912 (media online)

ISSN 2714-7150 (media cetak)

DOI 10.47065/josyc.v2i4.850

Interface data hasil Bumi merupakan halaman yang di gunakan untuk menambahkan Data-data item yang akan siap di akses oleh oleh custumer.

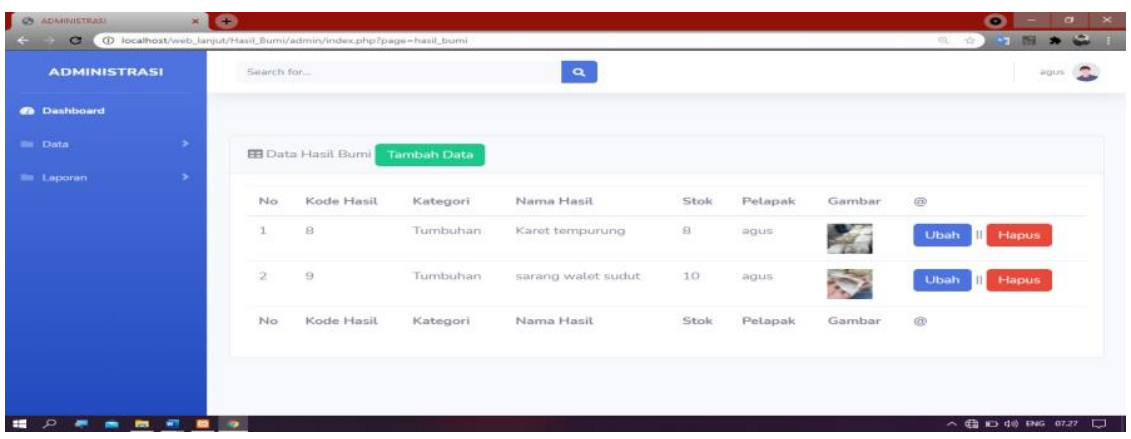

Gambar 6. Interface Input Data Hasil Bumi

Interface data custumer merupakan halaman yang digunakan untuk menambahkan data custumer guna untuk kelengkapan data.

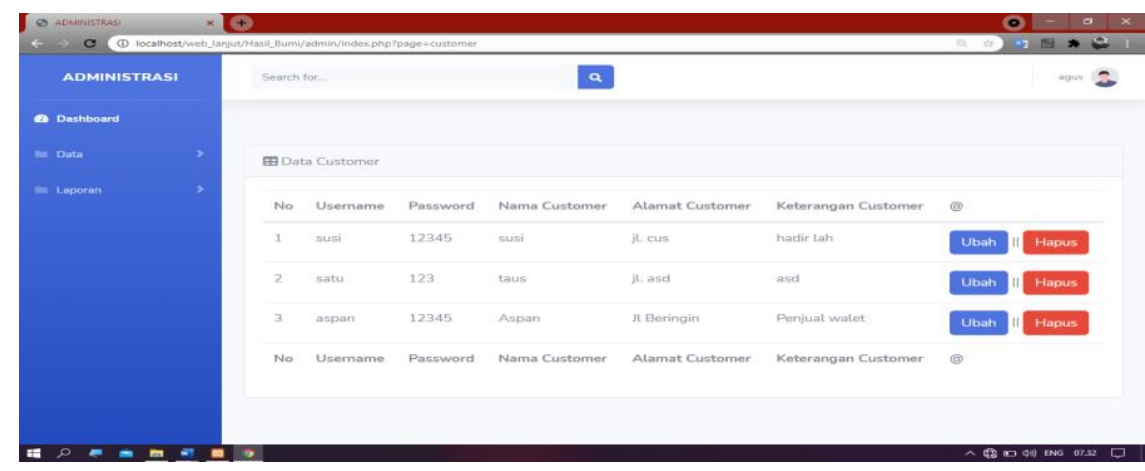

Gambar 7. Interface Input Data Custumer dan Pelapak

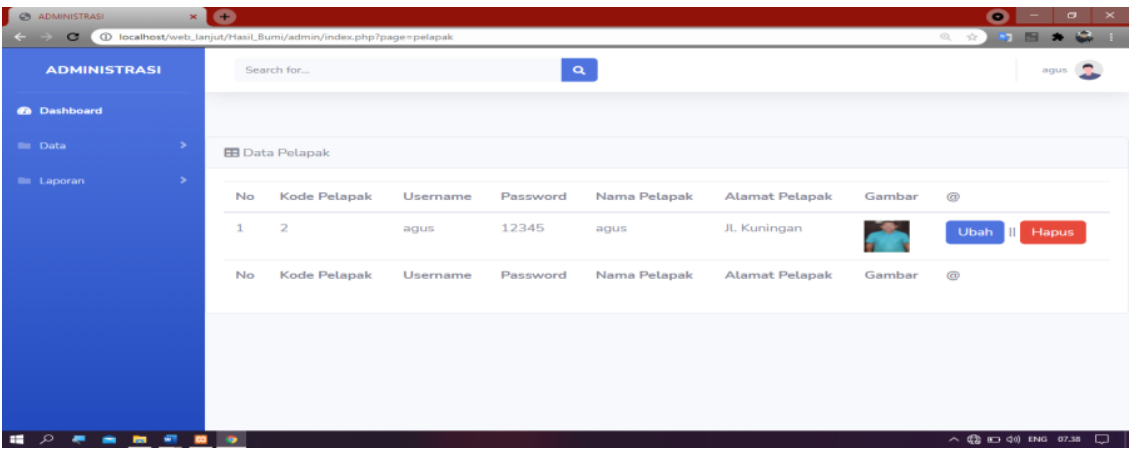

Gambar 8. Interface Input Data Custumer dan Pelapak

Interface data kategori merupakan halaman yang digunakan untuk menambahkan data kategori guna untuk dapat memasukkan nama keterangan kategori pada transaksi pembelian.

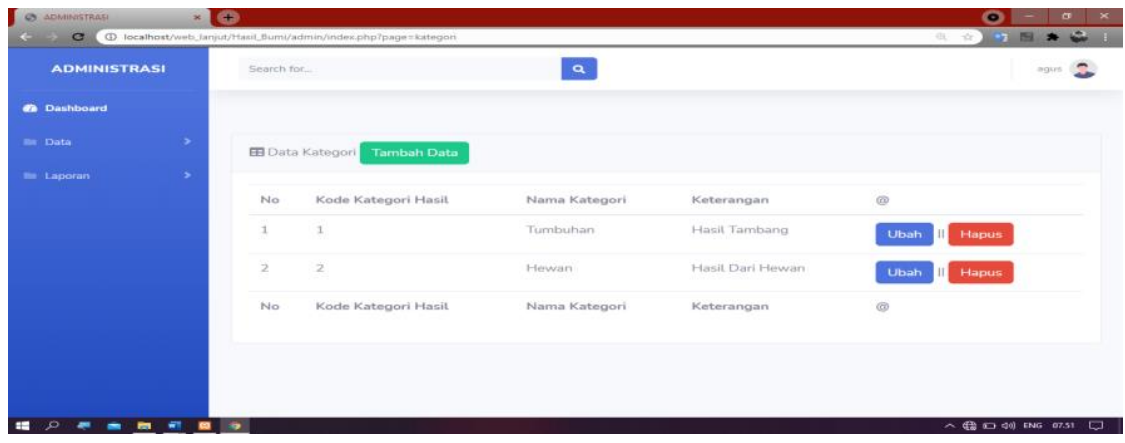

Gambar 9. Interface Input Data kategori

Interface Input Transaksi item hasil bumi sarang walet dan karet yang digunakan untuk menambahkan data oleh admin. 
Journal of Computer System and Informatics (JoSYC)

Volume 2, No. 4, August 2021, Page 310-315

ISSN 2714-8912 (media online)

ISSN 2714-7150 (media cetak)

DOI 10.47065/josyc.v2i4.850

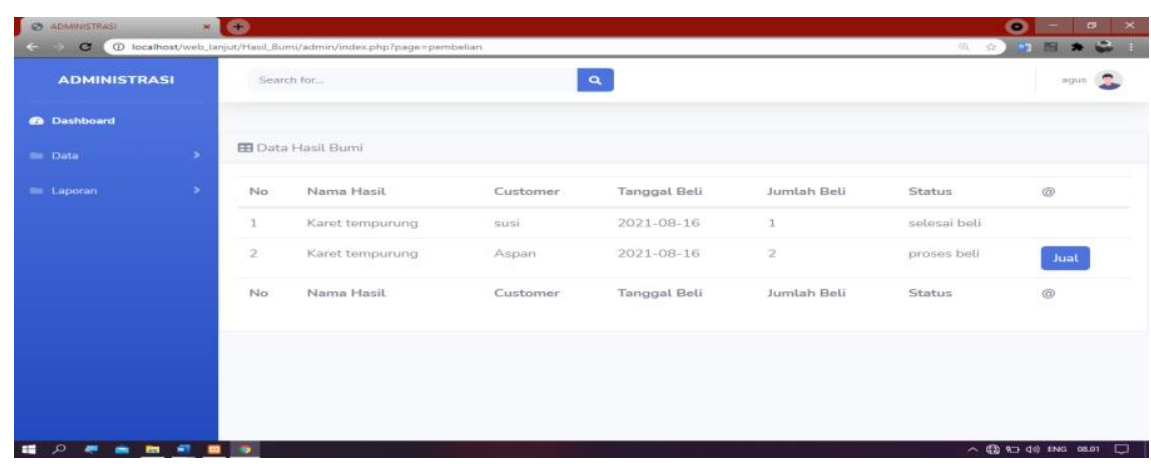

Gambar 10. Interface Input transaksi pembelian

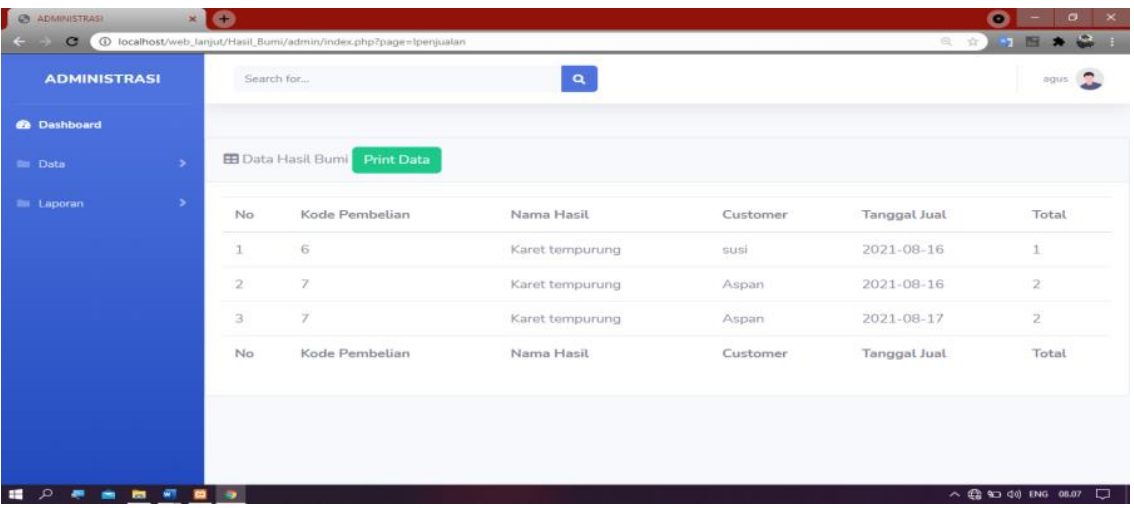

Gambar 11. Interface Input transaksi penjualan

Interface halaman laporan adalah halaman untuk mencetak laporan-laporan yang meliputi Daftar data hasil Bumi, custumer, pembelian, penjualan, pembayaran serta pengiriman dan semua transaksi pada sistem informasi yang dibuat.

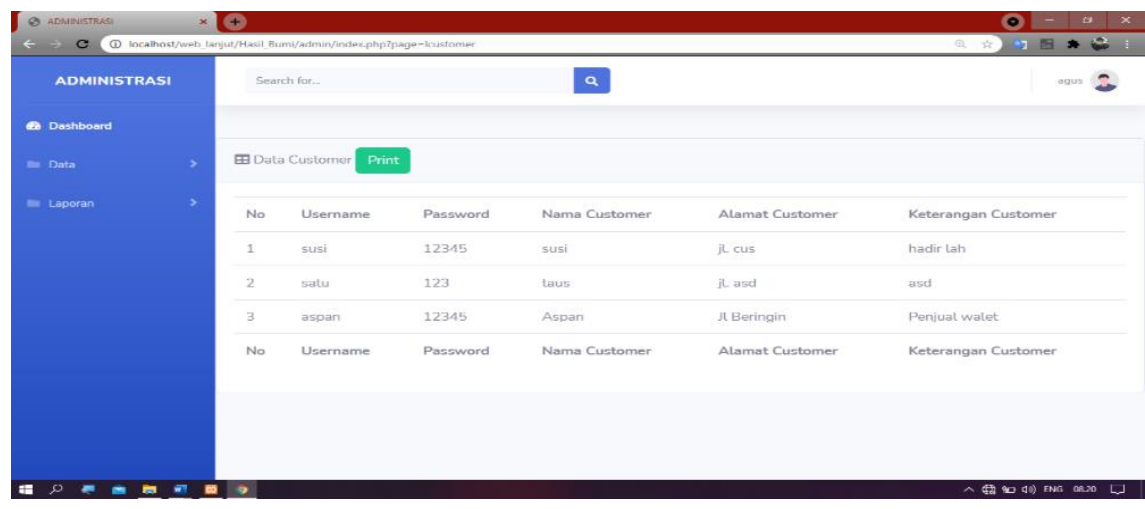

Gambar 12. Output Data Custumer

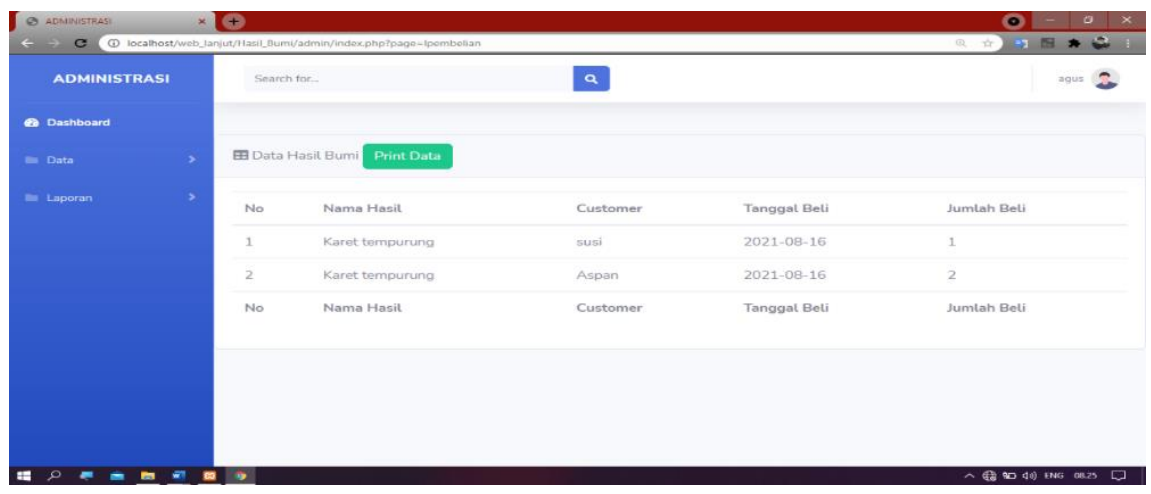

Gambar 13. Output Data Pembelian 
Journal of Computer System and Informatics (JoSYC)

Volume 2, No. 4, August 2021, Page 310-315

ISSN 2714-8912 (media online)

ISSN 2714-7150 (media cetak)

DOI 10.47065/josyc.v2i4.850

\section{KESIMPULAN}

Dari penelitian yang dilakukan, disimpulan dalam mengelola data master pada system informasi Hasil Bumi desa tumbang manjul kecamatan seruyan hulu kabupaten seruyan Berbasis Web dapat membantu dan mempermudah kalangan pengusaha serta masyarakat dalam proses berbisnis. Dengan di bangunnya Sistem Informasi Hasil Bumi Desa Tumbang Manjul daerah seruyan Hulu kabupaten seruyan Berbasis Web,pada proses transaksi yang terjadi pada system yang berjalan masih ada Bug atau kesalah fungsi sehingga bisa dilakukan pengembangan seacara berkelanjutan oleh peneliti selanjutnya. Adanya program Sistem Informasi Hasil Bumi Bumi Desa Tumbang Manjul daerah seruyan Hulu kabupaten seruyan Berbasis Web,dalam penyusunan laporan dari sebuah transaksi dapat di lihat dan di cek,dan di sajikan baik bentuk visual maupun secara fisik dalam sebuah media output (di layar monitor atau kertas).

\section{REFERENCES}

[1] T. S. Jaya and D. K. Widyawati, "Pengembangan E-Market Place Pertanian Dengan Metode Prototype Development of Agricultural E-Marketplace By Prototype Method," 2019.

[2] S. Kasus, K. Pringsewu, and K. Pagelaran, "APLIKASI E-MARKETPLACE PENJUALAN HASIL PANEN IKAN LELE,” vol. 1, no. 1, pp. 111-117, 2020.

[3] P. Sistem, I. E. Original, and L. Belakang, "Jurnal manajemen informatika," vol. 5, no. 2, 2018.

[4] J. Sundari and E. R. Nainggolan, "E-Marketplace Desa Gerabah Untuk Pengrajin Di Desa Bumi Jaya Serang Banten," J. Ind. Serv. Vol. 3 No. la Oktober 2017, vol. 3, no. 1, pp. 68-73, 2017.

[5] F. Teknik, "PEMBANGUNA APLIAKASI MARKETPLACE PROPERTY DENGAN FITUR PRICE FORECASTING MEMANFAATKAN LOCAATION BASED SERVICE PADA SMARTPHONE ANDROID."

[6] D. M. Informatika, F. Teknik, U. N. Surabaya, T. Informatika, F. Teknik, and U. N. Surabaya, "siRANCANG BANGUN APLIKASI E-MARKETPLACE HASIL PERTANIAN BERBASIS WEBSITE DENGAN MENGGUNAKAN FRAMEWORK CODEIGNITER Iin Sofiani Andi Iwan Nurhidayat Abstrak."

[7] V. Iffah, "Analisis Strategi Bisnis E-Commerce Perusahaan Startup Digital di Ijadfarm Surabaya,” 2018.

[8] I. K. Juliany, M. Salamuddin, and Y. K. Dewi, "PERANCANGAN SISTEM INFORMASI E-MARKETPLACE BANK SAMPAH BERBASIS WEB," pp. 19-24, 2018. 